\title{
Acts of Sovereignty as a Restriction on Judicial Control
}

\author{
Sabah Mousa Al Momani ${ }^{1}$ \\ ${ }^{1}$ Faculty of Law, Al -Balqa Applied University, Jordan \\ Correspondence: Sabah Mousa Al Momani, Faculty of Law, Al -Balqa Applied University, Jordan. E-mail: \\ sabah.momani@bau.edu.jo
}

Received: October 30, 2019

Accepted: December 30, 2019 Online Published: February 29, 2020

doi:10.5539/jpl.v13n1p110

URL: https://doi.org/10.5539/jpl.v13n1p110

\begin{abstract}
Theory of Sovereign Acts is of a judicial origin. It was created by the French Council of State to face political circumstances experienced by France in the early part of the last century. However, this Theory is still operative to date though justifications of its survival vanished.

This theory has been sternly criticized by most of jurists due to its violation of the Principle of Legality and the democratic principles. However, it is still effective under laws and judiciary refuses to have control over it.

Given the importance of this theory and its seriousness, this study aims to clarify the concept and origin of acts of sovereignty and the criteria used to distinguish it from other acts carried out by the government. This study also aims to show the position of jurisprudence, legislation and the judiciary on the acts of sovereignty that are immune from judicial control.

In spite of the democratic progress and the individuals' increased awareness of their rights, this study concludes that the laws still provide for these acts and make them immune from the judicial control.

However, the judiciary has started to to restrict the scope of acts of sovereignty, and to adopt the theory of acts detachable from acts of sovereignty, where it has started to control acts of sovereignty and to approve compensation for some of these acts.

This study concludes that the Theory of Sovereign Acts was created by judiciary to face certain conditions and causes that do not exist anymore. Hence, the provisions protecting acts of sovereignty from the judicial control must be repealed for violation of the principles of legality, justice and democracy.
\end{abstract}

Keywords: acts of sovereignty, immunity, detachable acts, compensations, principle of legality

\section{Introduction}

The Principle of Legality, which requires that the governors and the governed are subject to law, is one of the most important guarantees to protect individuals' rights and freedoms. However, establishing the Principle of Legality can only be realized through the judicial control over all administrative acts, where the administration is given broad powers. Thus, it has become necessary to control all administrative acts to ensure that they do not violate the principle of legality. Yet, this principle does not apply in the absolute sense, as the judicial control over some of the administrative acts, including acts of sovereignty, has been restricted for special considerations. This expressly undermines the principle of legality. This theory is one of the most serious exceptions to the principle of legality. It has been sternly criticized by most jurists. Some jurists have denied its existence, while some have considered it stigma attached to legality. This is because it puts the government beyond control and sometimes allows it to violate individuals' rights and freedom without any control over its acts on the pretext that they are sovereign acts.

\subsection{Problem of the Study}

The problem of the study is exempting acts performed by the administration, i.e. acts of sovereignty, from the judicial control/. Such exemption violates the principle of legality which requires that all person, whether governors or the governed, are subject to the law. Further, it violates individual's rights and freedoms, where individuals' right to sue the administration if it violates their rights and freedoms is guaranteed.

\subsection{Significance of the Study}

This study is significant since it defines the concept and scope of the Theory of Sovereign Acts due to its impact 
on the principle of legality and since it is an exception to such principle, which requires not to expand it. Hence, this study is very significant to determine scope of such theory and explain the criteria provided to define it.

\subsection{Objectives of the Study}

This study aims to clarify the negative impact of Theory of Sovereign Acts on the individuals' rights and freedoms. It has become, therefore, important to restrict scope of this theory, expand application of the theory of acts detachable from acts of sovereignty and approve the compensation for damage caused to individuals by application of this theory. Rather, it has become necessary to cancel application of this theory and repeal the provisions providing for such theory, this is because it was created by the French Council of State for political circumstances then faced by the Council and there is no reason to maintain it effective to date.

\subsection{Methodology of the Study}

The nature of this study requires combining the appropriate descriptive approach, to define the concept and criteria of acts of sovereignty that differentiate them from other administrative acts, and the analytical approach to analyze the legal texts and jurisprudence related to the acts of sovereignty. This is in order to read and analyze these texts and judicial principles to conduct an accurate and detailed study on the acts of sovereignty.

Upon the foregoing, this study is divided into four topics:

- Nature of Acts of Sovereignty

- Criteria for defining acts of sovereignty

- Theory of Sovereign Acts in Jurisprudence, Legislation and Judiciary

- Modern Trend for Restricting Theory of Sovereign Acts

\section{Nature of Acts of Sovereignty}

The right to litigation is one of the most important rights exercised by an individual, where constitutions have guaranteed this right. This right becomes more important if the litigant is the administration, where all administrative decisions issued by the executive power must be subject to control of administrative justice in terms of annulment and compensation. This means that every individual having an interest may request the competent jurisdiction to annul the administrative decision if it is legally defective. ${ }^{1}$

However, some decisions issued by the executive power are not subject to the judicial control. Such decisions are called acts of sovereignty or acts of government. This expressly violates the principle of legality, which provides that all people, whether governors or governed, are subject to the rule of law.

Thus, it is one of the most serious privileges of the administration at all, since considering some act as an act of sovereignty requires immunity from judicial control.

What does acts of sovereignty mean? How was this theory emerged?

These questions will be answered in the two following requirements.

\subsection{The Concept of Acts of Sovereignty}

The concept of acts of sovereignty is one of the most serious concepts in modern legal systems, since it is contrary to the principle of legality, which requires that everyone is subject to the law.

The definition of acts of sovereignty differs from one country to another. The concept of acts of sovereignty narrows in countries with long-established systems of democracy and expands in other countries.

Acts of sovereignty is defined as " the acts performed by the executive power and shaped with special considerations like internal and external safety of the state and is not subject to the court control if judicial power so decides"

They are also defined as "a set of actions performed by the executive power that are immune from all types or aspects of judicial control, whether annulment control, compensation control or legality examination control"3.

According to some jurists, acts of sovereignty means "a set of actions and procedures performed by the executive power that are not subject to judicial control, which is an express deviation from principle of legality and its

\footnotetext{
${ }^{1}$ Hafez Mahmoud (1993) Administrative Justice in the Egyptian Comparative Law, $1^{\text {st }}$ edition, Dar Nahda Arabia, Cairo, p.3.

${ }^{2}$ Tammawi, Sulaiman (1967), Administrative Justice, $1^{\text {st }}$ Book, Annulment Justice, Dar Fekr Arabi, Egypt, p.421.

${ }^{3}$ Hafez, Mahmoud (1993), Administrative Justice in the Egyptian Comparative Law, ibid.
} 
provisions".

According to the Egyptian Administrative Court, acts of sovereignty means "the actions performed by the government as a governing authority rather than an administration authority"s.

According to the Jordanian High Court of Justice, acts of sovereignty means "the actions performed by the government as a governing authority rather than an administration authority, and are immune from all types and aspects of judicial control"6.

The said Court also says in this context "the decisions issued by the executive power in connection with the state sovereignty, enforcement of the basic constitutional laws and movement of other powers are sovereign acts"7.

All above definitions agree that acts of sovereignty are immune from annulment control and compensation control. It is therefore an absolute judicial immunity that cannot be controlled by courts.

However, despite this agreement, it is noticed that the administrative jurisprudence and justice have failed, despite attempts, to develop an all-encompassing and accurate definition of acts of sovereignty. This was recognized by the Egyptian Administrative Court, where it ruled that: “... no all-encompassing and accurate definition of acts of sovereignty has been developed, where a normal administrative act could be upgraded, under certain political circumstances in a country, into an act of sovereignty. Yet, some acts of sovereignty could be degraded, under other circumstances, into administrative acts"

This is due to ambiguity of Theory of Sovereign Acts and its disagreement with the principle of legality and rule of law.

However, we appreciate attempts of jurisprudence and justice to define acts of sovereignty in order to restrict and control such acts so that rights and freedoms of individuals are protected.

\subsection{Emergence of Theory of Sovereign Acts}

Theory of Sovereign Acts was created by the French justice. It was created by the French Council of State established by Napoleon Bonaparte in 1798.

However, this theory did not emerge at the beginning of the establishment of the French State Council and throughout the first empire, but at the end of the monarchy in France and the emergence of the first republic. During the period prior to this era in the history of France, the judiciary had not interfered in the administration's actions and decisions. The decisions of the Council of State were also subject to approval of the President of the State, who had the final authority to approve them. Hence, there was no need for protecting some acts of the executive power since it had the last word in its decisions ${ }^{9}$.This stage was called the stage of restricted jurisdiction.

Following the fall of the first empire and the return of the monarchy to France in 1814, the French Council of State had been viewed with suspicion because it was remnant of the former regime and an extension of Napoleon's rule ${ }^{10}$. So, the Council of State wanted to keep its existence without conflicting with this monarchy, where its judiciary tried to find a legal solution to avoid risks of conflicting with the ruling regime in order to maintain existence of the Council ${ }^{11}$. Hence, it created Theory of Sovereign Acts that is based on protecting some actions of the executive power, in connection with the system of government, from the judicial control. It goes without saying that the French Council of State created this theory and prevented courts from controlling these acts.

\footnotetext{
${ }^{4}$ Shaer, Ramzi (no date), Compensation Justice, the State's Responsibility for its Non-Contractual Actions, $3^{\text {rd }}$ edition, Dar Tayseer for Printing, Cairo, p.277.

${ }^{5}$ Decision of Administrative Court No. (5/587), dated 26.6.1951, published in the set of legal principles decided by court of the State Council, referred to in Kayed, Ziad (2017), Acts of Sovereignty and the State's Responsibility, and Position of Jordanian Courts on Them, Manara Journal for Research and Studies, volume 23, issue 1, p.405.

${ }^{6}$ High Court of Justice, decision No. (1997/340), dated 19.10.1997 (ordinary judicial body) Journal of Jordanian Bar Association, 1997, issue 1, p.4547.

${ }^{7}$ High Court of Justice, decision No. (42/81), Journal of Jordanian Bar Association, year (31), issue 5, p.660.

${ }^{8}$ Court of Administrative Justice, dated 19.1.1956.

${ }^{9}$ Khalil, Muhsen (1967), Principles of Administrative law, $2^{\text {nd }}$ part, Lebanese Administrative Justice and Control of Adminisrative Acts ( a comparative study), Dar Nahda Arabia, Egypt, p.274.

${ }^{10}$ Bozian, Elian (2009), Legality State between Theory and Application, a comparative study-Sharia and Law, Dar Jama Jadida, Alexandria, pp.419-421.

${ }^{11}$ Bodiaf, Ammar (2007), Administrative Decision, Legislative, Judicial and Juristic Study, ${ }^{\text {st }}$ edition, Dar Jusoor, Algeria, p.67.
} 
The first case faced by the Council and drove it to create this theory was Lafitte Bank Case, in which the French government refused to deliver the funds donated to family of Napoleon. The French Council of State felt embarrassed when Lafitte Bank challenged the decision of the government in order to decide its legality. On $1 / 5 / 1822$, the Council issued a decision that the government rejects the challenge submitted by the Bank on the ground that the plaintiff's request relates to a political issue that should only be decided by the government.

During the reign of the second empire, the legal situations stabilized and the Council gained the confidence of the Government, where it recovered its status. In accordance with the Law issued on 24.5.1872, the French legislator decided to grant the Council the authority of final determination of the disputes lodged with it without any comments by any person. The Council had therefore the final judicial power. This stage was called the stage of an authorized judiciary ${ }^{12}$.

Against the support made to it by the government, the French Council of State sought to maintain Theory of Sovereign Acts that prevents the judicial control as price paid by the Council for being granted the authorized judicial power. The Council of State has kept approving this theory to date. Hence, Theory of Sovereign Acts was judicially established. It was created by the French Council of State, not by the French legislator.

However, the question arises here is how could we differentiate between the acts of sovereignty, that are not subject to the judicial control, and the administrative decisions that are subject to the judicial control, and what are the criteria provided in this respect?

\section{Criteria for Differentiation of Acts of Sovereignty}

Finding a criterion for differentiation between acts of sovereignty and other acts performed by the administration has been one of the most important problems faced by the administrative jurisprudence. The administrative jurisprudence has developed several criteria that can be summarized in three criteria as explained in the following three requirements:

\subsection{Political Motive Criterion}

This was the first criterion in France to differentiate between the sovereign acts and administrative acts ${ }^{13}$. The French Council of State used this criterion in Lafitte Bank Case, where the judgment in this case is the cornerstone in adoption of this criterion.

According to this criterion, an act is considered sovereign if its motive is political, so it is not subject to judicial control. Otherwise, it is an administrative act that is subject to the judicial control. The defective point in this criterion is that it does not explain how to determine the political motive, and when a motive is considered political. It seems that this criterion needs another criterion to define it.

Hence, this criterion has been sternly criticized by jurists in several respects. It is inaccurate and it cannot be relied upon to differentiate between sovereign acts and administrative acts; an act could be political and administrative at the same time. Further, this criterion expands scope of decision circle that is not subject to judicial control, and involves a risk that violates individuals' rights and freedoms, where deciding whether an act is political or not is entrusted to the executive power itself, and it decides if it is subject to the judicial control or not. If the executive power declares that there is a political motive beyond the act, then it is not subject to the judicial control, so this power will always invoke this to expand scope of acts that are not subject to the judicial control on the ground of a political motive. This this criterion a dangerous weapon that threatens individuals' rights and freedoms ${ }^{14}$.

Perhaps there were justifications and political circumstances beyond existence of this criterion, where the French Council of State is still governed by the idea of a restricted judiciary, where its decisions were subject to ratification by the president of state, and thus was normal for it to go along with the government as to its higher directions. The Council was unable to confront it, so it was obliged to go along with it to maintain it survival and to strengthen its existence. ${ }^{15}$

The French Council of State relied on this criterion in many decisions. This is evident in its decision issued on 9.5.1867 concerning decision of the Minister of Interior for confiscation of a book maintained with a publisher for defaming the government. The French Council of State considered the decision as a political act, and thus the

\footnotetext{
${ }^{12}$ Khalil, Muhsen (1967), ibid, p.273.

${ }^{13}$ Khalil, Muhsen (1967), ibid, p.421 ff

${ }^{14}$ See: Tammawi, Sulaiman (1967), ibid, p.278 ff, Khalil, Muhsen (1967), ibid, p.278, and Shatnawi, Ali Khattar (2011), Encyclopedia of Administrative Justice, $1^{\text {st }}$ part, $3^{\text {rd }}$ edition, Dar Thaqafa for Publication and Distribution, Amman, Jordan, p. $89 \mathrm{ff}$.

${ }^{15}$ Jurf, Tuaima (1976), Principle of Legality and Criteria for Governing Public Administration by Law, Dar Nahda Arabia, Cairo, p.76.
} 
Council did not have the power to look into the case brought to it against this decision. ${ }^{16}$

In view of risks of this criterion on the rights and freedoms of individuals, the French Council of State had abandoned it since the end of the nineteenth century after the stability of the situation and the growth of national awareness and the growing sense of citizens' freedoms. In its decision of 1880, the Court of Conflict affirmed that the criterion of political motive should be neglected, and that it was insufficient to keep administrative decisions away from judicial control. ${ }^{17}$

The Egyptian administrative court has adopted this criterion. It ruled that "it is established in this court that the acts of sovereignty are the higher actions and procedures to organize relationship with other internal or external public authorities..."18

Further, Jordanian administrative justice has adopted this criterion in many decisions, the High Court of Justice ruled that: "the state supreme policy aimed to support Iraq in repelling the Iranian state's aggression in implementation of the charter of joint defense already held between the Hashemite Kingdom of Jordan and the United Arab Republic, so this policy is an act of sovereignty and must be implemented by the administrative apparatus" ${ }^{\prime 19}$.

\subsection{Nature of Act Criterion (Objective Criterion)}

This criterion appeared on the ruins of the criterion of political motive. (After its failure, the jurisprudence conducted research on an objective criterion to differentiate between acts of sovereignty and other administrative decisions.

Under this criterion, acts of sovereignty are determined according to nature of the act performed by the executive power, and whether such act is governmental or administrative in nature.

Since both governmental and administrative decisions are issued by the executive power, then controls to determine them must be known, whether it is a governmental decision that is not subject to the judicial control or an administrative decision that is subject to such control.

Though the administrative jurists have agreed on necessity of finding a specific objective criterion that can classify acts of sovereignty in one range, it seems that they have not agreed on nature of such objective criterion. ${ }^{20}$

Some jurists argue that the act is governmental if it is meant to achieve interest of the political group, respect its constitution, internal security and foreign relationships, monitor its public bodies and supervise its relationship with foreign countries. It is administrative and governed by the judicial control when it is connected to the daily application of laws and regulation of the individuals' relationship with the central or local administration, and relationships of public departments with each other. ${ }^{21}$

Other jurists argue that nature of the objective criterion is determined according to the legal ground the government relies upon, where an act is deemed to be an act of sovereignty if it is for implementing a constitutional provision. If it is for implementation of legal professions, regulations and instructions, then it is an administrative and it is therefore subject to the judicial control.

Obviously, this opinion involves a great risk since it gives the administration an opportunity to exploit the constitution to make a lot of its acts fall within acts of sovereignty once it finds a constitutional ground. Thus, this does not agree with the wisdom of development of constitutions, where peoples have fought for a long time to develop written constitutions in order to protect their rights and freedoms. How these constitutions would become a tool to undermine these rights and freedoms. ${ }^{22}$

Another defective aspect of this opinion is that it leads to confusion between administrative acts and acts of sovereignty. The court considers a lot of acts as acts of sovereignty while they are not for implementation of constitutional provisions. Further, many administrative acts are for implementation of constitutional provisions

\footnotetext{
${ }^{16}$ Hamli, Mohammad (2018), Acts of Sovereignty Theory and Position of Algerian Justice and Comparative Justice, Journal of Kuwaiti Faculty of Law, $6^{\text {th }}$ year, issue 4, p.237.

${ }^{17}$ Qubailat, Hamdi, (2018), Wajeez in Administrative Justice, $3^{\text {rd }}$ edition, Dar Wael for Publication and Distribution, Jordan, p.81.

${ }^{18}$ Judgment of Administrative Court, year 1957, $11^{\text {th }}$ judicial year, referred to in Ukasha, Hamdi yasin (2001), Encyclopedia of Administrative Decisions in jurisdiction of the Council of State, Dar Kutub Masria, Egypt, p.566.

${ }^{19}$ High Justice Court, decision No. 87/7, Journal of Jordan Bar Association, 1982, issue 3, p.341.

${ }^{20}$ Shatnawi, Ali Khattar, ibid, p.89.

${ }^{21}$ Tammawi, Sulaiman, ibid, p.331.

${ }^{22}$ Kamel, Mustafa (1954), Council of State, Maktabat Nahda Masria, Egypt, p.191.
} 
while the court does not consider them acts of sovereignty, such as appointment of employees, etc. ${ }^{23}$

A third part of jurists have tried to differentiate between acts of sovereignty and the administrative decisions depending on nature of the function carried out by the executive power. The executive power does two different functions, governmental and administrative. If the act of government is for carrying out its governmental function, then the act is sovereign and it is therefore not subject to judicial control,. Yet, if it is for carrying out its administrative function, then it is an administrative act that is subject to the judicial control.

This opinion has been criticized for ambiguity, since it replaces a difficulty with another difficulty, where how we could differentiate between the governmental and administrative jobs.

The Jordanian administrative justice has adopted this criterion in several decisions as a ground for differentiating between acts of sovereignty and other administrative acts. The High Court of Justice rules that "acts performed by the executive power are divided into two types: administrative acts and political acts, where the former are subject to the control of court, while the latter are out of control of this court". ${ }^{24}$

It also ruled that "the decisions related to the acts of sovereignty are the actions performed by the executive power as a governing authority, unlike the administrative decision issued by the executive power as an administrative authority". ${ }^{25}$

Yet, this criterion did not work due to the huge amount of criticisms against it, and due to its inability to find objective and formal controls to differentiate between the governmental and administrative acts.

\subsection{Judicial List Criterion}

After the failure of jurists to set a comprehensive criterion preventing acts of sovereignty, they decided to leave the matter of determining these acts to the administrative justice itself, since it is the body that created this theory and is able to indicate its scope and extent Jurist are only required to refer to the judicial judgments and stick to the acts of sovereignty that are considered as such by judiciary then, they are required to collect them in a coordinated group so that they are easily referred to and examined. Many jurists have supported this view, including Horio Wableton. ${ }^{26}$

Having reviewed the judicial judgments, jurists have attempted to classify some of acts that are deemed to be sovereign acts in the form of a judicial list composed of four groups:

\subsubsection{Acts Related to the Relationship between the Executive and Legislative Powers}

These acts include the decisions issued by the executive power in connection with the parliamentary election, calling for holding and adjourning house of regenerative, adjournment of its sessions, adjournment of the ordinary and extraordinary session of parliament, dissolution of parliament, suggestion of draft laws submitted by the government to the parliament, etc.

In many occasions, the French administrative justice has stressed that these acts are not subject to its control since they are sovereign acts.

In several decisions, the High Court of Justice asserted this. It ruled that "according to the provisions of Article 3/34 of the Jordan Constitution "the King may dissolve the Chamber of Deputies", the constitution adopts the royal (not ministerial) dissolution of the parliament. 2- Acts of sovereignty are the acts performed by the government as a governing authority rather than an administrative authority, and it is immune from all types of judicial control pursuant to Article 9/h of the Law of High Court of Justice. 3- justifications for dissolution of parliament are not subject to the judicial control since they are political act, since His Majesty, the King has the discretion to determine the reasons for dissolution of the parliament. Hence, the High Court of Justice does not have jurisdiction over the challenge against the royal decree for dissolution of the parliament". ${ }^{27}$

\subsubsection{Acts Related to the International Relations}

This group includes the international conventions and agreements, where signature, negotiation, termination and ratification of such conventions are sovereign acts that are not subject to the judicial control.

This has been approved by the Jordan administrative justice, where the High Court of Justice ruled that " the

\footnotetext{
${ }^{23}$ Tammawi, Sulaiman, ibid, p.424.

${ }^{24}$ High Court of Justice, decision No. 52/34, 1952/1/1, Journal of Jordan Bar Association, issue 1, dated 1/1/1952.

${ }^{25}$ High Court of Justice, decision No. 1996/9, 30/3/1996, Journal of Jordan Bar Association, issue 1, dated 1/1/1997.

${ }^{26}$ Bozian, Elian, ibid, p.413.

${ }^{27}$ High Court of Justice, decision No. 1997/340, 19/10/1997, Journal of Jordan Bar Association, issue 1, dated 1.1.1997.
} 
administrative court does not have jurisdiction over the challenges based on violation of provisions of conventions by the government and against individuals, whether such violation is refrainment by the government to implement provisions of the convention for the benefit of the plaintiff, or implementation of the convention by the government contrary to the convention itself, or issuance of a decision that is not in line with the provisions of the convention. The dispute based on these matters does not fall within jurisdiction of the administrative court since it relates to the acts of sovereignty". ${ }^{28}$ Further, this group includes decisions of representatives of the state in performing their diplomatic duties, and the decisions related to the actions brought before the international courts". 29

\subsubsection{Acts Related to War Actions}

The administrative justice has determined that the acts performed by the executive power in connection with war actions are sovereign acts and rejected to control them.

This group includes the declaration of war decision, conciliation agreement, military operations carried out as a result of the war, measures taken for the nationals of the enemies such as deportation, detention and custody of their funds, as well as requests arising from the hostilities, as well as damage caused by foreign armies during their staying in the territory of another State, exchange of prisoners and invitation of reservists to serve.

The French Council of State refused to discuss legality of the wars in which the State engages, and refused to examine legality of military operations and their compensation as they are sovereign acts.

\subsubsection{Decisions Related to Safety and Internal Security of the State}

These acts are considered the most serious acts performed by the executive power since they relate to impairment of individual's rights and freedoms, especially if courts go further in defining their scope and extent.

Indeed, this group has been sternly criticized by jurists, where some jurists have denied its relevance to the acts of sovereignty.

These acts include the declaration of a state of emergency and the declaration of martial law. The French administrative justice has adopted this and it considered that the acts related to the safety of the State and issuance of martial law decree by the executive power are acts of sovereignty and they are not subject to the judicial challenge.

Since this group endangers the individuals' rights and freedoms, the French Council of State has started to restrict its scope, where it, in the beginning of the fifties of the last century, ceased to consider the martial law declaration decision an act of sovereignty and made it subject to control. ${ }^{30}$

The Egyptian administrative court did the same. It ruled that "it is established in this court that the deportation orders in general are of the state internal security related measures, and not of acts of sovereignty". ${ }^{31}$

The Jordan administrative justice adopted approach of the French Council of State and considered that the acts related to the state safety and internal security acts of sovereignty. The High Court of Justice ruled that "the King is the only person, who has the right to determine existence or non-existence of the state of emergency, and this court cannot challenge such determination, otherwise the court would deprive the king of this power and give it to itself". ${ }^{32}$

Moreover, the Jordan administrative court has followed approach of the French and Egyptian administrative justice, where it started to restrict acts of sovereignty. It differentiated between the royal decree issued in the state of emergency or the martial law (as acts of sovereignty) and extraordinary control procedures issued in any of the above cases). It considered that these procedures are administrative decisions and subject to the control of the administrative court,. It ruled that "it is established in the administrative jurisprudence and judiciary of the High Court of Justice that the acts of sovereignty are the acts or procedures performed by the government as a governing authority not an administrative authority and as it represents interest of the state in order to organize its relations with other public authorities and supervise its relations with the foreign countries). Hence, the decision issued by the Economic Security Committee, based on Article 5 of Instructions of Customary

\footnotetext{
${ }^{28}$ High Court of Justice, decision No. 1966/51, 1/1/1966, published on system.jba.org.jo

${ }^{29}$ Qubaliat, Hamdi, ibid, p.86.

${ }^{30}$ Shatnawi, Ali Khattar, ibid, p.94.

31 Appeal No. 282 of year 4, judicial, Egypt, dated 8.4.1952.

${ }^{32}$ High Court of Justice, 24/2/1952, Journal of Jordan Bar Association, 1953, p.54, referred to in Shatnawi, Ali Khattar, ibid, p.94.
} 
Management of Financial and Economic Affairs No. 2 of 1967, is an administrative and not a sovereign act". ${ }^{33}$

\section{Theory of Sovereign Acts in Jurisprudence, Legislation and Judiciary}

Most jurists think that Theory of Sovereign Acts is a blatant attack on the principle of legality and consider it a stigma attached to legality. However, legislations still include these acts in legal provisions, paying no attention to jurists' demands to remove such acts from the legal system. Further, the judiciary still disassociates itself from controlling several administrative acts on the grounds that such acts are sovereign. Consequently, position of jurisprudence, legislation and judiciary on Theory of Sovereign Acts will be discussed in three requirements.

\subsection{Position of Jurisprudence on Theory of Sovereign Acts}

Jurisprudential opinions differed on Theory of Sovereign Acts though most jurists have denied it and demanded to vanish it.

These jurists believe that Theory of Sovereign Acts is an affront to the principle of legality and rule of law, leading to hinder individuals' rights and freedoms. They also agrue that this theory constitutes a constitutional violation, where the legal legislator and judiciary cannot exempt the administrative act from the judicial control, since the right to litigation is guaranteed under the constitution and is non-derogable.

Further, the democratic system requires that acts of the executive power is subject to the judicial control by challenging them under annulment and compensation actions ${ }^{34}$, where jurisdiction can accommodate all disputes concerning rights and freedoms and the relationship between the governor and the governed without restriction.

Nevertheless, some jurists support this theory and agrue that it is a realistic legal fact that cannot be denied though they think that it contradicts the principle of legality and affects individuals' rights and freedoms.

Supporters of this trend justify their opinion that interest and integrity of the state require that some acts of government should not be subject to judicial control, and they think creation of this theory reflects the wise and flexible policy of the French Council of State to protect its existence after the government reduced its authority and powers, where the Council found that it is better to reconcile with it, and created the so-called acts of sovereignty.

The researcher thinks that this justification may be suitable for the previous historical stage experienced by the French Council of State, but now and after lapse of this time and after the spread and dominance of democracy, it is no longer appropriate to maintain this theory and it is no longer accepted since an act of the executive power is beyond judicial control on the pretext that it is an act of sovereignty.

Given the serious effects of Theory of Sovereign Acts, some jurists have sought to mitigate these effects by compensating individuals who have been affected by its application.

The researcher supports this trend, where nothing prevents bringing a compensation case for the damages caused to individuals due to application of Theory of Sovereign Acts.

\subsection{Position of Legislation on Theory of Sovereign Acts}

Most of the legislations that adopt Theory of Sovereign Acts did not provide for acts that are considered sovereign However, they provided that the judiciary does not have jurisdiction over these acts, and therefore they are not subject to the judicial control and no case in connection with these acts may be tried.

The French Council of State created Theory of Sovereign Acts in France. This means that it stemmed from a judicial (not legislative) origin. However, some jurists argue that Article 26 of the French Law of 1872 can serve as a legislative basis for this theory, where it provides that "the Ministers may bring the cases brought to the Council of State that are beyond jurisdiction of the administrative courts before the Conflict of Jurisdiction Court".

This view was sternly criticized by some jurists, who believe that this Article does not serve as a legal basis for Theory of Sovereign Acts, since this Article aims to realize a kind of balance between the two sides of the judiciary, by giving ministers the power to extract cases that are beyond the jurisdiction of the administrative justice and bring these cases before the Conflict of Jurisdiction Court. ${ }^{35}$

The researcher supports this opinion where the provisions of the said Article cannot serve as a legislative basis for Theory of Sovereign Acts.

\footnotetext{
${ }^{33}$ High Court of Justice, decision No. 1990/202, 1/1/1990, Journal of Jordan Bar Association, issue 4, 1991, p.781.

${ }^{34}$ Jamal Eddin Sami (1992), Control of Administrative Acts, Administrative Justice, Alexandria (no publisher), and p.561.

${ }^{35}$ Kayed, Ziad, ibid, p.419.
} 
In Egypt, Theory of Sovereign Acts was built on a legislative basis, where there are explicit provisions in the Egyptian legislations that emphasize immunity of sovereign acts.

The Hybrid Courts Classification Regulations of 1900, and the Civil Courts Classification Regulations of 1937 provide for immunity of acts of sovereignty, and the successive Egyptian Council of State laws provide that they do not have jurisdiction over the requests in connection with acts of sovereignty.

These acts were initially defined as examples. However, the Egyptian legislator departed from this by not defining these acts, where Article 12 of the law No. 165 of 1955 provides that "the Council of State shall not have jurisdiction, as an administrative justice body, over the requests in connection with acts of sovereignty" ${ }^{36}$

As to Jordan, the administrative justice, represented by the High Court of Justice, acknowledges that it does not have jurisdiction over acts of sovereignty unless it is legislatively decided.

The High Court of Justice ruled that "the acts performed by the executive power are divided into administrative acts and sovereign acts, where the former type is subject to control of this court... while the latter cannot be tried by the court". ${ }^{37}$

If we review the Jordanian legislations, we will find that Formation of Civil Courts Law No. 26 of 1952 has no indication to the acts of sovereignty, where they are only mentioned in the amended Formation of Civil Courts Law No. 38 of 1963. Article 10 of the said Law, which deals with jurisdiction of the Court of Cassation in the capacity of a high court of justice, provides that the requests submitted for challenging the decisions on acts of sovereignty are rejected.

The said Article kept effective until issuance of Formation of Civil Courts Law No. 12 of 1989, where Article 10 thereof was amended that it does not indicate to rejection of the requests concerning acts of sovereignty due to mentioning formation of the high court of justice, where its formation, powers and trial proceedings before it are determined under a law to be issued for this purpose.

In this context, the temporary High Court of Justice Law No. 11 of 1989 was issued, where Article (9/b) thereof provides that "no challenge against any decision concerning any act of sovereignty brought before the high court of justice shall be accepted".

After the said Law had been ratified by the Parliament, the permanent High Court of Justice Law No. 12 of 1992 was issued. The said law emphasizes the previous Article, where Article 9/c/1 thereof provides that "the High Court of Justice shall not have jurisdiction over the requests and challenges in connection with acts of sovereignty".

More than two decades later, the Administrative Justice Law No. 27 of 2014 was issued. It contains the same article, neglecting the democratic progress and the increased awareness of individuals of their rights, Para (d) of Article 5 of the said Law provides that "the Administrative Court shall not have jurisdiction over the requests and challenges in connection with acts of sovereignty".

All these provisions show that the Jordanian legislator did not define nature of acts of sovereignty, nor did he explain how to differentiate these acts from other administrative acts. Rather he merely required that he has no jurisdiction over acts of sovereignty related challenges, leaving determination of such acts to the jurisprudence and the judiciary.

The question that arises here is, are civil courts permitted to look into the challenges in connection with acts of sovereignty? Noting that the Jordanian Formation of Civil Courts Law does not provide for lack of jurisdiction of such civil courts.

The researcher argues that absence of a provision preventing the civil courts from looking into the requests and challenges related to acts of sovereignty in the Formation of Civil Courts Law does not give it the right to look into such requests and challenges, since acts of sovereignty are administrative decisions issued by the executive power, and they must be therefore challenged before the administrative courts. This is emphasized in Article 5/a of the Administrative Justice law No. 27 of 2014, which provides that "the Administrative Court shall have exclusive jurisdiction to hear all challenges relating to the final administrative decisions....."

Thus, challenging all administrative decisions is before the administrative and not before civil courts, where acts of sovereignty are deemed as administrative decisions that are not subject to the judicial control since they are

\footnotetext{
${ }^{36}$ Abd Al-Baset, Mohammad Fuad (1989), Acts of Administrative Authority, Alexandria University, p.136-137.

${ }^{37}$ High Court of Justice, decision No. (1952/34), 1/1/1952, Journal of Jordanian Bar Association, issue 1, published on 1/1/1953, published on system.jba.org.jo
} 
issued by the government as a governing not administrative authority, as explained above.

\subsection{Position of Judiciary on Theory of Sovereign Acts}

We have noticed that Theory of Sovereign Acts stemmed from judicial origin. It was created by the French Council of State in line with the political circumstances surrounding it at that time. Despite disappearance of these circumstances, this theory has been applied in the French judiciary to date.

However, the French judiciary has tried to restrict the scope of this theory as much as possible, where it granted itself the power to decide whether an act is sovereign or not ${ }^{38}$, after this power had been attached to the executive power.

Further, the French judiciary carried out several actions with the aim of narrowing the scope of acts of sovereignty. It considered declaration of state of emergency administrative decisions issued by an administrative authority that can be challenged before the Council of State. In many occasions, it used the theory of decisions that are detachable from acts of sovereignty to make them administrative and they are therefore subject to its control with the aim of restricting scope of acts of sovereignty.

The Egyptian High Administrative Court adopts Theory of Sovereign Acts The said court mentioned the theory in many decisions, for instance, the decision of the Administrative Court in 1951, where it ruled that "it established in this court that the acts of sovereignty are the actions performed by the government as a governing authority rather than an administration authority, where it performs such actions under the high authority to regulate its relationships with other public authorities...,39

Having reviewed decisions of the Egyptian administrative justice, it is found that it did not rely on a specific criterion to differentiate between acts of sovereignty and other acts. Rather, it used various criteria in different occasions such as the political motive criterion, nature of work criterion and the judicial list criterion.

The Egyptian administrative justice adopted the approach of the French administrative justice by narrowing the scope of acts of sovereignty, and by removing some acts from the scope of acts of sovereignty. It considered them administrative acts and started to control them, such as the decision of the President of the Republic concerning declaration of the state of emergency. After the said declaration had been an act of sovereignty that is beyond control of the administrative court, the administrative justice considered it an administrative act that is subject to the judicial control. In this context, the Egyptian Administrative Court ruled that “... the power of the President of the Republic to declare and extend the state of emergency has ceased to be an absolute power, rather it is a restricted power...".

The Court found that: "the decision No. 587 of 2013 issued by the President of Republic to extend the declared state of emergency, under decision No. 532 of 2013, for two months is an administrative decision and is not considered an act of sovereignty..." 40

The Jordanian administrative justice had adopted, like the French and Egyptian administrative justice, Theory of Sovereign Acts in many decisions before it provided for it in its legislations. However, it did not use a certain criterion to differentiate between acts of sovereignty and other administrative acts. In some decisions, it used the political motive criterion, while it used the objective criterion in other decisions, and it also used the judicial list criterion.

The High Court of Justice ruled that "the petitioner's loss of the right to return to the West Bank under the instructions of the occupation authorities due to not returning to the West Bank upon the expiry of his permit does not cancel his permanent residence there, This which means that the petitioner is considered a resident of the West Bank. The decision of disengagement that considers every person habitually resides in the West Bank before 31/7/1988 a Palestinian national is an act of sovereignty". "The said decision shows that the court issued this decision based on the political motive criterion.

The High Court of Justice used nature of work criterion (objective criterion) in another decision. It ruled that "the acts of sovereignty related decisions are the decisions issued by the executive power in connection with the sovereignty of the state, execution of the basic constitutional laws and movement of other authorities such as the government ties with parliaments and state ties with foreign countries. This does not apply to the administrative

\footnotetext{
${ }^{38}$ Tammawi, Mohammad Sulaiman (2006), General Theory of Administrative Decisions, $1^{\text {st }}$ edition, Dar Fekr Arabi, Cairo, p.141.

${ }^{39}$ Decision of Administrative Court No. (5/587), dated 26.6.1951, case No. 587, set of the $5^{\text {th }}$ year.

${ }^{40}$ Court's Decision of Egyptian administrative justice on 12/11/2013, Judiciary Case No. 74029 of 67, referred to in Al Hamli, Mohammad, ibid, Page No. 253.

${ }^{41}$ High Court of Justice, decision No. 91/188, Journal of Jordanian Bar Association, 1992, p.378
} 
decision issued by an administrative authority that enforces laws and regulations with the aim of creating a certain legal position wherever it is legally possible and permitted, where such decision is appealable before the High Court of Justice". ${ }^{2}$

In another decision, on 29.10.1997, the High Court of Justice dismissed the case filed by the petitioner for challenging the royal decree on dissolution of the parliament. The court ruled that "justifications of dissolution of parliament are not subject to judicial control as they are a political act, where His Majesty is authorized to consider the causes for dissolution of the parliament. Hence, the High Court of Justice does not have jurisdiction to look into the appeal against the royal decree for dissolution of parliament". ${ }^{43}$

The High Court of Justice ruled that the declaration of state of emergency and declaration of martial law are acts of sovereignty, where this decision is an application of the judicial list criterion, since the court exercised discretion and ruled that these matters take place in exceptional circumstances, and thus the court is prevented from controlling them since they are sovereign acts". ${ }^{44}$

We hope that the Jordanian judiciary will follow the French judiciary's approach by simplifying its control over the decisions concerning declaration state of emergency and martial law, so that they are considered administrative acts and are placed under its control. Moreover, we hope that the Jordanian judiciary will remove these decisions from the scope of sovereign acts, as they affect the rights and freedoms of individuals.

\section{Modern Trend for Restricting Theory of Sovereign Acts}

Since Theory of Sovereign Acts affects the principle of legality and the rights and freedoms of individuals, the administrative jurisprudence and judiciary have begun to restrict the acts that fall within the acts of sovereignty in order to narrow their scope.

The French Council of State removed many acts from the list of acts of sovereignty. For instance, conclusion of international treaties and conventions is an act of sovereignty. The Council of State, however, considered that the executive acts in connection with application of treaties are administrative acts that are subject to the judicial control.

Moreover, though declaration of state of emergency is a sovereign act, jurisprudence considered the procedures taken to implement it administrative procedures that are subject to the judicial control. Emergence of the theory of the acts detachable from the acts of sovereignty contributed to restricting Theory of Sovereign Acts, where some jurists acknowledge that there is a set of procedures performed by the administration to implement the political act but they are irrelevant to it, so these decisions are administrative and are, therefore, subject to the judicial control.

Detachable act means "a decision that is not directly and inevitably associated with an act of sovereignty, rather it is made for existence of such act and is not directly arisen from it or necessary for its existence". ${ }^{4}$

According to the said definition, it is noticed that the detachable decisions are final administrative decisions and thus are subject to the judicial control.

The French administrative judiciary applied the theory of acts detachable from acts of sovereignty in many decisions, where it applied them to extradition procedures and to the decisions that could be separated from international treaties and conventions and from diplomatic relations.

The Jordanian administrative court also applied the theory of sovereign acts detachable from acts of sovereignty to Jordan-West Bank disengagement decision. Though this decision is an act of sovereignty, any administrative decision issued according to this decision without being directly associated with it is deemed to be a detachable decision. The High Court of Justice ruled that "the acts of sovereignty related decisions are the decisions issued by the executive power in its capacity as a governing power. This does include the administrative decisions issued by the executive power in its capacity as an administrative authority. This decision is considered administrative and is appealable before the High Court of Justice. Thus, since the challenged decision, concerning cancellation of the petitioner's passport and family booklet, was issued by director of the Civil Status and Passport Department to rectify a position under the law, then it is an administrative decision that is

\footnotetext{
${ }^{42}$ High Court of Justice, decision No. 1981/41, 1/1/1981Journal of Jordanian Bar Association, year (31), $5^{\text {th }}$ issue, p.660. published on system.jba.org.jo

${ }^{43}$ High Court of Justice, decision No. 1997/340, 1997/10/19, published on system.jba.org.jo.

${ }^{44}$ Kayed, Ziad, ibid, p.413.

${ }^{45}$ Abd Al-Wahhab, Mohammad Refat (no date), Administrative Justice, $1^{\text {st }}$ book, Halabi Publications, Lebanon, Beirut, p.242.
} 
appealable by cancellation". ${ }^{46}$

We appreciate our administrative justice for adopting this theory since it has considerably mitigated effects of acts of sovereignty on rights and freedoms of individuals, and we hope that application of this theory is expanded.

In many countries, the administrative justice has recently tended to establish responsibility for acts of sovereignty and to restrict their effects by confining their effects to immunity against annulment without compensation based on the theory of taking responsibility and the principle of persons equality in public burdens. It unfair that a person is affected by acts of sovereignty and cannot claim compensation. ${ }^{47}$

Approval of compensation will greatly contribute to reducing effects of acts of sovereignty in the administrative justice. If cancellation of acts of sovereignty is unfeasible now, the considerable progress concerning compensation has a significant effect in the reparation for damage caused by application of acts of sovereignty.

In some of its decisions, the French Council of State has tended to establish State responsibility for treaties and conventions with other States and international organizations and decided that compensation is paid to the individuals affected by the implementation of these treaties.

We hope that our judiciary will follow approach of the French judiciary by approving compensation for acts of sovereignty in reparation for damage caused to individuals by the application of the theory of sovereign acts.

\section{Conclusion}

Acts of sovereignty is a setback to the principle of legality, where it is a serious exception that affects rule of law and threatens individuals' rights and freedoms.

Jurists almost unanimously agree that acts of sovereignty are a stigma attached to the rule of law and legality. However, legislators of most countries still provide for these acts in their laws and legislative provisions, despite the democratic progress and the individuals' increased awareness of their rights and freedoms. For example, the Jordanian Administrative Justice Law No. 27 of 2014 incorporates these acts in Article 5/d, repeating the same provision contained in the High Court of Justice Law No. 12 of 1992.

We hoped that the Jordanian administrative legislator would repeal this provision and be aware of its negative impact on the individuals' rights and freedoms. Accordingly, it would not have been included in a relatively new legislation. Unfortunately, this did not happen. Rather the Jordanian administrative justice had applied Theory of Sovereign Acts even before it was included in legislation.

Hence, having examined Theory of Sovereign Acts including its emergence and application, a set of findings and recommendations are provided.

\subsection{Findings}

- The principle of legality requires that all people, whether governors or governed, are subject to the law where none is above the law.

- In principle, all administrative acts should be subject to the judicial control to verify their legality.

- Emergence of acts of sovereignty is associated with the French Council of State, where it had created these acts, and then countries adopted them and included them in their laws.

- The Jordanian legislator requires that judiciary does not have jurisdiction over the acts of sovereignty.

- The Jordanian administrative justice had applied Theory of Sovereign Acts and had made some administrative acts beyond its control even before the law provided for it.

- There are many criteria for differentiating between acts of sovereignty and other administrative acts.

- The judiciary is the only body that determines whether an act is sovereign or administrative according to a criterion provided for in jurisprudence.

- Given that Theory of Sovereign Acts affects the individuals' rights and freedoms, the modern trend has started to restrict its scope and adopt the theory of acts detachable from acts of sovereignty. Further, some countries have started to establish responsibility for acts of sovereignty and approve the compensation for the damage caused by such acts.

${ }^{46}$ High Court of Justice, decision No. 1996/9, published on system.jba.org. jo

${ }^{47}$ Wasel, Mohammad, ibid, p.391. 


\subsection{Recommendations}

- The researcher recommends that Article 5/d of the Administrative Justice Law No. 27 of 2014, which provides for lack of jurisdiction of the administrative court over the requests and appeals in connection with acts of sovereignty, is repealed since this Article contradicts the principle of legality and the right to litigation that is guaranteed by the constitution. We hope that this Article is repealed by the Jordanian legislator.

- We hope that our administrative justice will follow approach of the French and Egyptian administrative justice by restricting scope of acts of sovereignty and expanding the theory of acts detachable from acts of sovereignty, where this will reduce violation of individuals' rights and freedoms.

- We hope that our administrative justice will take a bold step by following the French and Egyptian approach and providing for the responsibility for acts of sovereignty and confining their effect to the immunity against annulment other than compensation. This will significantly contribute to reduction of the negative effects resulting from acts of sovereignty, so that this theory that violates the principle of legality is cancelled.

\section{References}

Abd Al-Baset, M. F. (1989). Acts of Administrative Authority. Alexandria University.

Abd Al-Wahhab, M. R. (n. d.). Administrative Justice (1st ed.). Halabi Publications, Lebanon, Beirut.

Bodiaf, A. (2007). Administrative Decision, Legislative, Judicial and Juristic Study (1st ed.). Dar Jusoor, Algeria.

Bozian, E. (2009). Legality State between Theory and Application, a comparative study-Sharia and Law. Dar Jama Jadida, Alexandria,

Hafez, M. (1993). Administrative Justice in the Egyptian Comparative Law (1st ed.). Dar Nahda Arabia, Cairo.

Hamli, M. (2018). Acts of Sovereignty Theory and Position of Algerian Justice and Comparative Justice. Journal of Kuwaiti Faculty of Law, 6(4).

Jamal Eddin, S. (1992). Control of Administrative Acts, Administrative Justice, Alexandria.

Jurf, T. (1976). Principle of Legality and Criteria for Governing Public Administration by Law. Dar Nahda Arabia, Cairo.

Kamel, M. (1954). Council of State. Maktabat Nahda Masria, Egypt.

Kayed, Z. (2017). Acts of Sovereignty and the State's Responsibility, and Position of Jordanian Courts on Them. Manara Journal for Research and Studies, 23(1).

Khalil, M. (1967). Principles of Administrative law, $2^{\text {nd }}$ part, Lebanese Administrative Justice and Control of Administrative Acts (a comparative study), Dar Nahda Arabia, Egypt.

Qubailat, H. (2018). Wajeez in Administrative Justice (3rd ed.). Dar Wael for Publication and Distribution, Jordan

Shaer, R. (n. d.). Compensation Justice, the State's Responsibility for its Non-Contractual Actions (3rd ed.). Dar Tayseer for Printing, Cairo.

Shatnawi, A. K. (2011). Encyclopedia of Administrative Justice (1st part, 3rd ed.). Dar Thaqafa for Publication and Distribution, Amman, Jordan.

Tammawi, M. S. (2006). General Theory of Administrative Decisions (1st ed.). Dar Fekr Arabi, Cairo.

Tammawi, S. (1967). Administrative Justice (1st ed.). Annulment Justice, Dar Fekr Arabi, Egypt.

Ukasha, H. Y. (2001). Encyclopedia of Administrative Decisions in jurisdiction of the Council of State. Dar Kutub Masria, Egypt.

\section{Copyrights}

Copyright for this article is retained by the author(s), with first publication rights granted to the journal.

This is an open-access article distributed under the terms and conditions of the Creative Commons Attribution license (http://creativecommons.org/licenses/by/4.0/). 